\title{
Micronutrients affecting leaf biochemical responses during pineapple development
}

\section{Aiala Vieira Amorim', Claudivan Feitosa de Lacerda², Elton Camelo Marques ${ }^{3}$, Francisco Jardelson Ferreira², Ricardo José da Costa Silva Júnior², Francisco Luciano Andrade Filho ${ }^{2}$, Enéas Gomes-Filho ${ }^{3 *}$}

'Universidade da Integração Internacional da Lusofonia Afro-brasileira, Redenção, CE, Brazil.

${ }^{2}$ Agricultural Engineering Department, Universidade Federal do Ceará (UFC), Fortaleza, CE, Brazil.

${ }^{3}$ Biochemistry and Molecular Biology Department, Instituto Nacional de Ciência e Tecnologia em Salinidade, UFC, Fortaleza, CE, Brazil.

*Corresponding author: egomesf@ufc.br

Received: November 27, 2012; Accepted: April 08, 2013

ABSTRACT: An adequate mineral nutrition is essential for the development and productivity of pineapple. However, little is known about the nutritional and metabolic changes that occur in this crop in response to micronutrient deficiency or excess, particularly on tropical conditions. Thus, the objective of this study was to evaluate the application effects of micronutrients in soil and in leaf on biochemical responses of leaves during the development cycle of the pineapple crop. Samples were collected at 3, 6, 9, 12, and 17 months after transplantation. Leaf soluble carbohydrates and $\mathrm{N}$-aminosoluble compounds were determined, as well as variations in the titratable acidity and $\mathrm{pH}$. The soil and leaf micronutrient application increased the concentrations of carbohydrates and $\mathrm{N}$-aminosoluble and reduced the leaf $\mathrm{pH}$, and the changes were more significant in the last sampling (17 months after transplantation). Reductions in concentrations of carbohydrates and increase in the titratable acidity of the pineapple leaves collected at the end of the night were also observed, a fact that reflects the metabolism of Crassulacean acid metabolism species. The strategy of micronutrient application contributes positively to alter the metabolism of plants of pineapple cv. Victoria, especially during flowering and fruit development.

KEYWORDS: Ananas comosus, carbohydrates, metabolism, mineral nutrition, titratable acidity.

The pineapple has always stood out in the horticulture, not only due to the qualities of its fruit, but also because of the high profitability and social importance, being an activity that requires labor-intensive in the field. Monitoring of the plant metabolism is important as vigorous plants with adequate mineral nutrition may produce a high-quality fruit (Soares et al. 2005, Agbangba et al. 2011).

When analyzing the photosynthetic metabolism, notably the cycle of carbon reduction, it was found that higher plants and algae developed mechanisms of $\mathrm{CO}_{2}$ concentration, which minimize losses related to photorespiration and enhance water use efficiency (Leegood 2002, Moroney and Ynalvez 2007). Crassulacean acid metabolism (CAM) is a striking example of convergent evolution that substantially improves plant water use efficiency, exceeding those of $\mathrm{C} 4$ and $\mathrm{C} 3$ plants by at least three and six times, respectively, enabling partial or predominant uptake of $\mathrm{CO}_{2}$ at night. At least 343 genera in 35 plant families are known to engage this photosynthetic specialization (Borland et al. 2011).

Pineapple belongs to the group of CAM plants, whose main characteristic is to close their stomata during the day and open them at night in order to save water (Martín, Rius and Podestá, 2011). In semiarid and arid conditions, similar to those of Northeast Brazil, CAM crops present comparative advantages, which enable them to produce food, paper, beverages, and pharmaceutical extracts through consecutive seasons (Borland et al. 2011). Thus, pineapple is a CAM crop adapted 
to maintain a positive carbon balance under a wide range of environmental stresses (Keller and Luttge 2005, José, Montes and Nikonova 2007).

The inadequate supply of a particular nutrient in the pineapple crop often results in metabolic and nutritional disorders that can compromise growth, yield, and fruit quality (Soares et al. 2005, Vieira et al. 2010). However, little is known about the nutritional and metabolic changes that happen in this crop in response to micronutrient deficiency or excess, particularly on tropical conditions (Siebeneichler et al. 2008, Feitosa et al. 2011, Maeda et al. 2011). The most important micronutrients in pineapple are iron, zinc, copper, and boron ( $\mathrm{Su} 1975)$. The supply of micronutrients in pineapple crop can be done by solid or liquid applications, the latter being the most used (Reinhardt and Cunha 2010). However, information that relates these types of micronutrient application with changes in metabolism during the development of this crop are rarely reported (Bartholomew et al. 2003). Therefore, the aim of this study was to evaluate the effects of soil and leaf application of micronutrients on leaf biochemical responses during the pineapple crop cycle.

The experiment was conducted from December 2008 to October 2010 in an irrigated area located in Marco county, at the Northern region of State of Ceará, Brazil ( $3^{\circ} 07^{\prime} 13^{\prime \prime} S$ and $\left.40^{\circ} 05^{\prime} 13^{\prime \prime} \mathrm{W}\right)$. According to the Köppen's classification, the climate type is Aw' (tropical raining). The experimental area soil is classified as "Typic Quartzipsamment", with a sandy texture and density of $1.590 \mathrm{~kg} \mathrm{~m}^{-3}$. The soil chemical characteristics at 0 to $20 \mathrm{~cm}$ depth are: $\mathrm{pH}=5.8 ; \mathrm{EC}=0.15 \mathrm{dS} \mathrm{m} \mathrm{m}^{-1}$; and $0.77,0.30,0.08,0.02$, and $0.75 \mathrm{cmol}_{\mathrm{c}} \mathrm{kg}^{-1}$ of $\mathrm{Ca}, \mathrm{Mg}, \mathrm{K}$, $\mathrm{Na}$, and $\mathrm{Al}$, respectively.

The experimental design was in split plot with four levels of soil fertilization, four of leaf fertilization, and five sampling times with 90 days intervals, including five repetitions. Each plot consisted of four subplots, having four double rows with 11 plants in each, and the evaluations were taken at the two central lines of every subplot. The experimental areas were mulched with bagana (the straw resulting from the extraction of the carnauba wax sheet) of carnauba (Copernicia prunifera).

For the soil fertilization, the commercial micronutrient formulation FTE-12 (9, 1.8, 0.8, 3 and 3\% of Zn, B, Cu, Fe and $\mathrm{Mn}$, respectively) was used. It was applied in the pits of each plot before planting at doses of $0,60,120$, and $180 \mathrm{~kg} \mathrm{ha}^{-1}$. The four levels of leaf fertilization were: LF0 (no fertilizer); LF1 (15 leaf fertilization applications, using 1158.8, 844.7, 391.5, 322.7 , and $216.0 \mathrm{~g} \mathrm{ha}^{-1}$ of $\mathrm{Fe}, \mathrm{Mn}, \mathrm{Zn}, \mathrm{Cu}$, and $\mathrm{B}$, respectively); LF2 (15 leaf fertilization applications, using twice the quantities applied in LF1); and LF3 (15 leaf fertilization applications, using three times the amount in LF1).
The leaf fertilization with micronutrients was performed monthly, and the concentrations were defined having as reference the modified Murashige and Skoog (1962) nutrient solution. The concentrations of the salts used in the micronutrient solution formulation in the first two applications are shown in Table 1. These initial ones were doubled in the three following usages, tripled in three other ones and quadrupled in the last seven. To facilitate uptake of micronutrients, it was used urea $2 \%$, which was added to all treatments from the third to the last application. The total volume of the solution in each application was $463 \mathrm{~L} \mathrm{ha}^{-1}$.

Macronutrients were applied to all plants via fertigation beginning two months after transplanting, following the same procedure done by producers. The total applied and the fertilizers used were as follows: $688,797,98,80,20$ e $24 \mathrm{~kg} \mathrm{ha}^{-1}$ of urea, $\mathrm{K}_{2} \mathrm{SO}_{4}, \mathrm{H}_{3} \mathrm{PO}_{4}, \mathrm{NH}_{4} \mathrm{H}_{2} \mathrm{PO}_{4}, \mathrm{Ca}\left(\mathrm{NO}_{3}\right)_{2}$ and $\mathrm{MgSO}_{4}$, respectively.

Ninety days-old pineapple seedlings (Ananas comosus L. Merril) cv. Vitória, which is a cultivar resistent to fusariosis (Ventura et al. 2009), were transferred from trays to black polyethylene plastic bags containing sand as substrate, with $800 \mathrm{~g} \mathrm{~m}^{-3}$ of simple superphosphate. They were acclimated under shade cloth with $50 \%$ of shading for six months and irrigated twice a week with water (electrical conductivity of $0.44 \mathrm{dS} \mathrm{m}^{-1}$ ) during this period. Transplantation was performed in April 2009, when the plants reached about $150 \mathrm{~mm}$; they were arranged in double rows, spaced $0.9 \times 0.4 \times 0.3 \mathrm{~m}$, with an area of $19.2 \mathrm{~m}$ wide and $44.0 \mathrm{~m}$ long, totaling 7,040 plants in 0.174 ha.

The leaf samples were taken at 3, 6, 9, 12, and 17 months after transplantation (MAT), the first four coinciding with the period of vegetative growth and the fifth corresponded to the time of development of inflorescences, as it was done about a month before harvesting. In each period, two leaves " $D$ " (the leaf of greater length among the youngest of pineapple) were taken randomly in two plants of each subplot. They were collected in the late afternoon (between 4 and $5 \mathrm{pm}$ ) and in the end of the night (between 4 and $5 \mathrm{am}$ ). The environmental conditions in each sampling time are shown in Table 2.

The leaves were wrapped in foil and stored in a refrigerator at $-20^{\circ} \mathrm{C}$ for about 72 hours. The frozen ones were ground in a mortar and whole juice from leaf tissues obtained was placed in

Table 1. Salt concentrations $\left(\mathrm{g} \mathrm{L}^{-1}\right)$ used in the formulation of micronutrients solution in the first two applications for different treatments

\begin{tabular}{llccc} 
Salts & LF0 & LF1 & LF2 & LF3 \\
$\mathrm{H}_{3} \mathrm{BO}_{3}$ & No application & 0.062 & 0.124 & 0.186 \\
\hdashline $\mathrm{CuSO}_{4} \cdot 5 \mathrm{H}_{2} \mathrm{O}$ & No application & 0.062 & 0.124 & 0.186 \\
\hdashline $\mathrm{ZnSO}_{4} \cdot 7 \mathrm{H}_{2} \mathrm{O}$ & No application & 0.086 & 0.172 & 0.258 \\
\hdashline $\mathrm{MnSO}_{4} \cdot 4 \mathrm{H}_{2} \mathrm{O}$ & No application & 0.169 & 0.338 & 0.507 \\
\hdashline $\mathrm{FeSO}_{4} \cdot 7 \mathrm{H}_{2} \mathrm{O}$ & No application & 0.278 & 0.556 & 0.834
\end{tabular}


Eppendorf tubes and immediately frozen to be used for determinations of soluble carbohydrates (Dubois et al. 1956) and $\mathrm{N}$-aminosoluble compounds (Yemm and Cocking 1955). The rest of the juice and the residue resulting from grinding were used for the measurement of $\mathrm{pH}$ and titratable acidity (TA). For these determinations, samples of $1.0 \mathrm{~g}$ were weighted and

Table 2. Air temperature $(\mathrm{T})$ and relative humidity $(\mathrm{RH})$ at 5 and 16 hours; the average temperature (TL) and relative humidity (RHL) of the light period; and the average temperature (TN) and relative humidity $(\mathrm{RHN})$ at night.

\begin{tabular}{|c|c|c|c|c|c|c|c|c|}
\hline \multirow{2}{*}{ Months } & T16 & T5 & TL & TN & RH16 & RH5 & RHL & RHN \\
\hline & \multicolumn{4}{|c|}{$\left({ }^{\circ} \mathrm{C}\right)$} & \multicolumn{4}{|c|}{$(\%)$} \\
\hline 3 & 26.7 & 21.7 & 23.8 & 22.1 & 77 & 95 & 91.5 & 94.2 \\
\hline 6 & 33.6 & 22.9 & 28.8 & 23.5 & 41 & 88 & 61.4 & 86.3 \\
\hline 9 & 28.8 & 24.2 & 26.9 & 24.4 & 65 & 90 & 78.9 & 89.7 \\
\hline 12 & 28.2 & 24.5 & 26.8 & 24.4 & 80 & 95 & 87.0 & 94.3 \\
\hline 17 & 34.1 & 23.8 & 29.4 & 24.5 & 35 & 83 & 56.5 & 81.3 \\
\hline
\end{tabular}

diluted with deionized water at a ratio of 1:50. The $\mathrm{pH}$ was determined by a $\mathrm{pH}$ meter. Then, three drops of a $1 \%$ phenolphthalein solution were added for determination of TA by titration with $0.1 \mathrm{~N} \mathrm{NaOH}$ solution (IAL 1985).

The data were submitted to analysis of variance (ANOVA), and the regression one was performed for data in which significant $(\mathrm{p}<0.05)$ effects occurred.

The two forms of micronutrients application caused increases in the concentration of carbohydrates in both late afternoon and in the end of the night (Figure 1). Regarding the sampling times, it was found that the highest responses were obtained at 12 and 17 MAT. Furthermore, it was concluded that the concentrations of soluble carbohydrates at the late afternoon were higher than those at the end of the night, indicating the consumption of carbohydrate in plant metabolism.

From the first to the last sampling time, the concentrations of carbohydrates in the late afternoon, in relation to
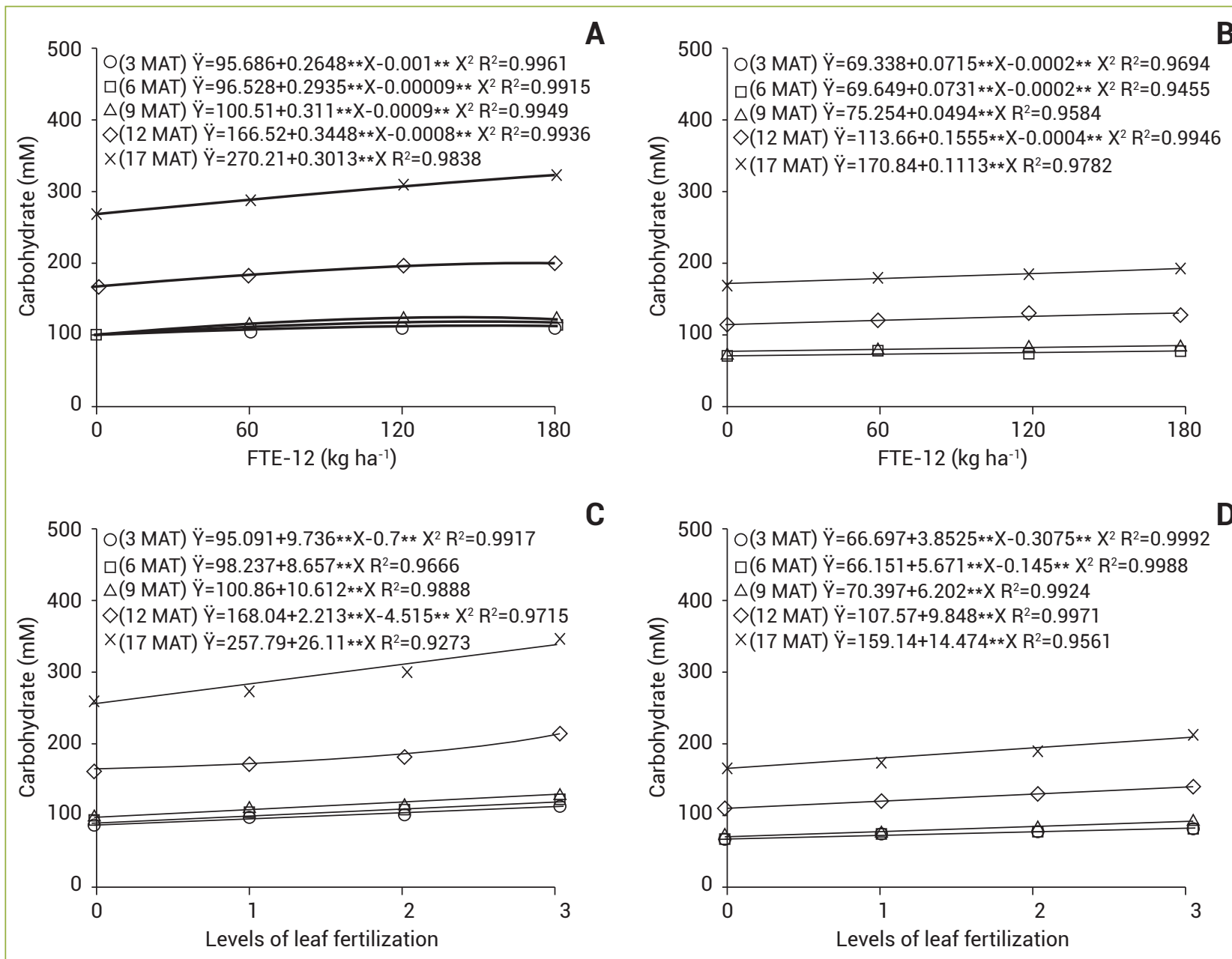

Figure 1. Concentrations of soluble carbohydrates in the leaves of pineapple cv. Vitória as a function of FTE-12 (A and B) doses and levels of foliar fertilization (C and D) at five sampling times $(3,6,9,12$, and 17 months after transplantation), analyzed at late afternoon (A and $\mathbf{C}$ ) and at the end of the night (B and $\mathbf{D})$. *p<0.05; $* * p<0.01$. 
FTE-12 doses, ranged from 95.69 to $270.21 \mathrm{mM}$ (1.8 times increase) at the dose of 0 and from 110.95 to $324.44 \mathrm{mM}$ (1.9 times increase) for the treatment containing $180 \mathrm{~kg} \mathrm{ha}^{-1}$ FTE-12 (Figure 1A). At the end of the night, the variation was from 69.34 to $170.84 \mathrm{mM}$ (1.5 times increase) for plants that were not receiving FTE-12, and from 75.73 to $190.87 \mathrm{mM}$ (1.5 times increase) at the highest dose of this micronutrient formulation (Figure 1B). Similar results were observed when using increasing levels of leaf fertilization (Figures 1C and D).

Likewise the concentrations of soluble carbohydrates, leaf concentrations of $\mathrm{N}$-aminosoluble compounds also showed increments provided by the two types of the micronutrient application (Figure 2), with the highest values observed at 12 and 17 MAT. The increase was linear for almost all plants, except for those subjected to treatment with FTE-12 at 12 and 17 MAT in those harvested at late afternoon (Figure 2A) and to those taken at $3 \mathrm{MAT}$ at the end of the night (Figure 2B), which showed quadratic behavior.

Despite TA not be changed significantly throughout the crop cycle, there were increases in TA in both types of micronutrient application (Figure 3), and the values at the end of the night were higher than those at late afternoon. The leaf $\mathrm{pH}$ values found herein decreased with increasing doses of micronutrients applied (Figure 4). The average of leaf $\mathrm{pH}$ changed from 4.74 at late afternoon to 3.5 at the end of the night, noting that the oscillations in TA between nighttime and day time on the leaves of pineapple were consistent with the values of $\mathrm{pH}$ in each period, therefore there is an inverse relationship between these variables.

Making up a joint analysis of variations in the concentration of carbohydrates between the end of the day and night, we observed that the largest differences occurred at the 12 and 17

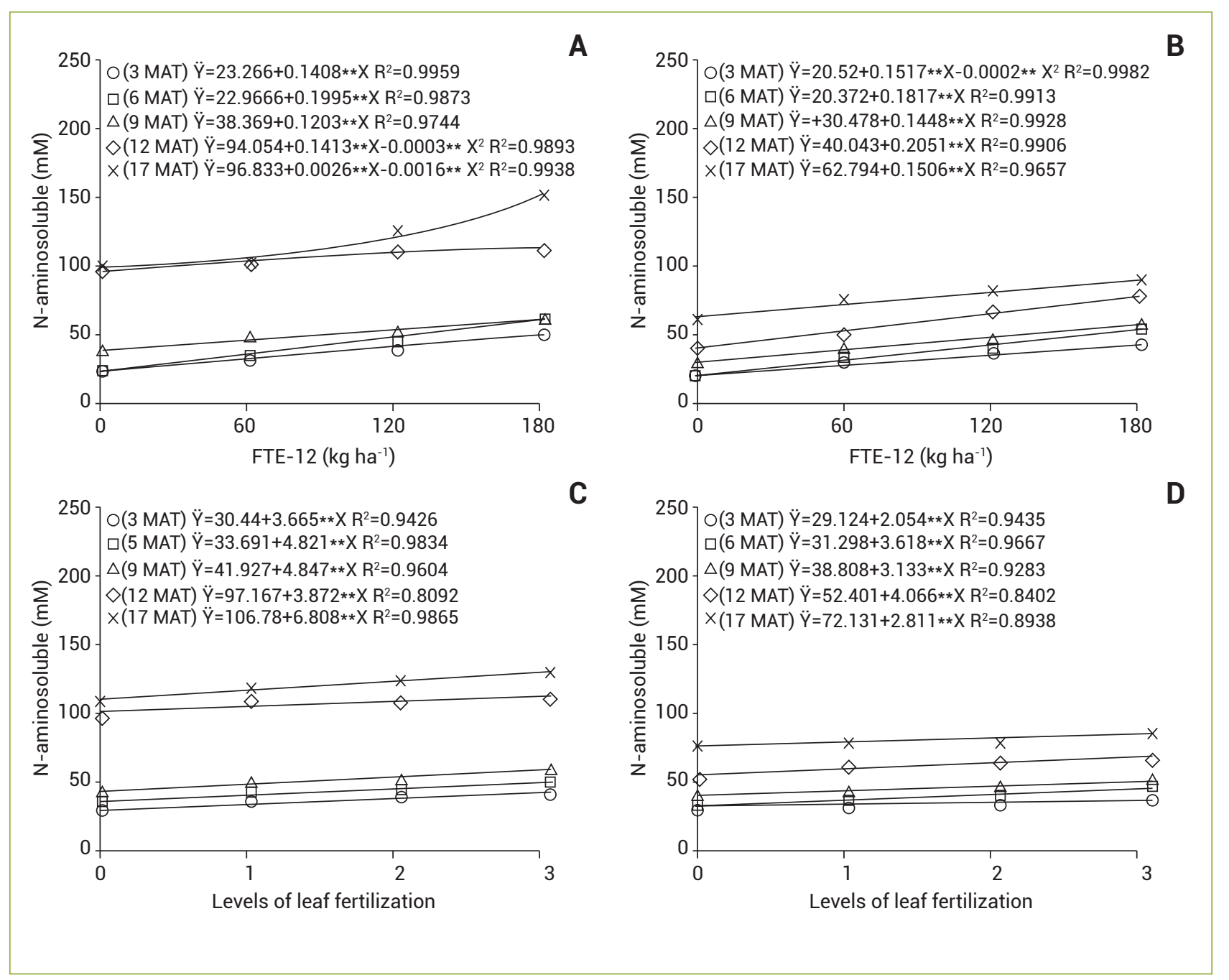

Figure 2. Concentrations of $\mathrm{N}$-aminosoluble compounds in leaves of pineapple cv. Vitória as a function of FTE-12 (A and B) doses and levels of foliar fertilization (C and D) at five sampling times $(3,6,9,12$ and 17 months after transplantation), analyzed at late afternoon (A and $\mathbf{C}$ ) and at the end of the night (B and $\mathbf{D}) . * p<0.05 ; * * p<0.01$. 
MAT (Figure 5). While at the first sampling time this variation was $33.6 \mathrm{mM}$, it reached $116.5 \mathrm{mM}$ at the last (Figure 5A).

Analyzing the relative reductions in the concentrations of soluble carbohydrates (late night towards the end of the day), it was also observed that the largest reductions occurred at the last sampling time (Figure 5B); however, the differences were less pronounced than the changes in absolute terms (Figure $5 \mathrm{~A})$. While in the first sampling time there is a reduction in carbohydrates concentrations of $30.9 \%$, in the last sampling it reached a $38.7 \%$ value. On the other hand, variations in TA were relatively small throughout the crop cycle (Figures 5C and D). TA showed increases of over $70 \%$ during the night, indicating the occurrence of CAM metabolism.

The highest accumulation of carbohydrates observed at the last sampling (Figure 1) can be explained in part by the physiological stage of plant development. During the formation of pineapple inflorescences, there is an increased demand for carbohydrate and other organic solutes. According to Carvalho et al. (1991), concentrations of total sugars in leaves of Smooth Cayenne pineapple were higher at the harvest of inflorescences.

The lowest leaf concentrations of soluble carbohydrates at night compared to day time (Figure 1) can be explained considering the nocturnal acidification of CAM plants (Ceuters et al. 2009). According to Borland and Taybi (2004), the circadian clock plays a central role in controlling many of the metabolic, transport, and physiological components of CAM. The level of control exerted by the clock can range from transcriptional to post-translational regulation, depending on genes, proteins, and even plant species. Further control is provided by metabolites, including organic acids and carbohydrates, which show substantial reciprocal fluctuations in content over the daily cycle.

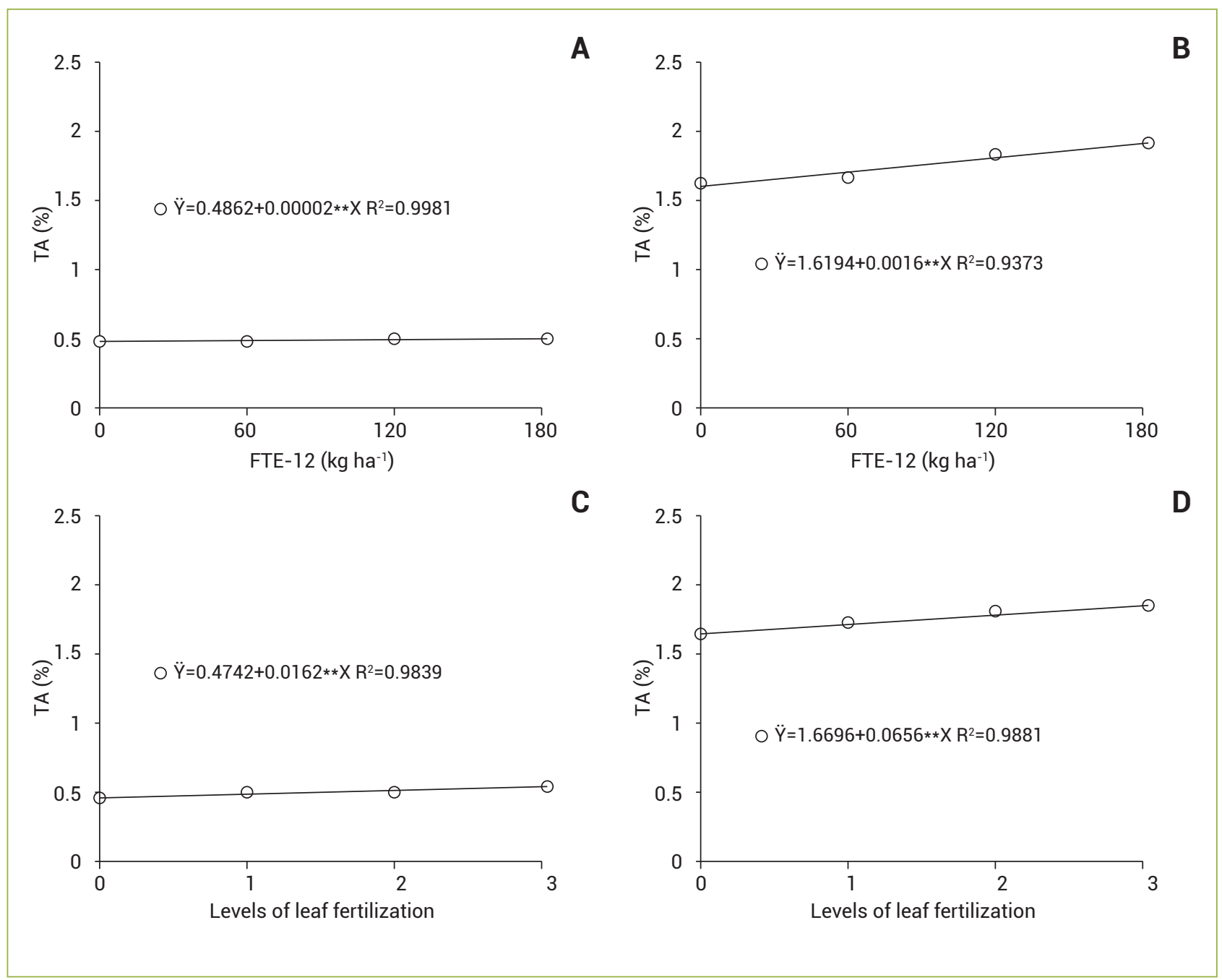

Figure 3. Titratable acidity (TA) in the leaves of pineapple cv. Vitória as a function of FTE-12 (A and B) doses and levels of foliar fertilization ( $\mathbf{C}$ and $\mathbf{D})$ at five sampling times $(3,6,9,12$ and 17 months after transplantation), analyzed at late afternoon (A and $\mathbf{C})$ and at the end of the night $(B$ and $D)$. * $p<0.05 ; * * p<0.01$. 
The carbohydrate used for the synthesis of organic acids can vary between CAM species. While pineapple uses soluble carbohydrates, in most plants the starch is the source of hexoses for malate synthesis (Carnal and Black 1989, Cushman et al. 2008). Study conducted by Chen, Lin and Nose (2002) demonstrated in CAM plants the occurrence of increases in concentrations of glucose-6-phosphate, fructose-6-phosphate and glucose-1-phosphate at the early hours of the night and decreases at the end of this period. The results suggest that hexoses-P produced in glycolysis may be in more excess than that required to malate accumulation during the first part of dark period, while the opposite may be the case during its latter part. These authors also found that the concentrations of the abovementioned three hexoses were higher in leaves of pineapple than in two other CAM species: Kalanchoe daigremontiana and K. pinnata.

The highest leaf concentrations of $\mathrm{N}$-aminosoluble compounds at the last two sampling periods (Figure 2) may be associated with reproductive stage of plants, which demand a larger amount of these solutes for flowering and forming inflorescences. Independent of the fertilizer type, the concentrations of $\mathrm{N}$-aminosoluble compounds observed at the late afternoon were higher than those seen at the end of the night, mainly the ones of the two last samples (12 and $17 \mathrm{MAT}$ ). This indicates that amino acids can also have contributed to the production of organic acids during the night, using reversible reaction of Krebs cycle. $\mathrm{N}$-aminosoluble compounds represent an important fraction of the pool of soluble nitrogen from leaf tissues and they are also important for maintaining the $\mathrm{pH}$ of the cell, protecting macromolecules, and eliminating reactive oxygen species (Mansour 2000). In the present study, it was found that leaf concentrations of $\mathrm{N}$-aminosoluble compounds (Figure 2) in pineapple plants cv. Vitória showed trends similar to those for concentrations of carbohydrates (Figure 1), which is an indication of the strong interaction between the metabolism of carbon and nitrogen (Huppe and Turpin 1994).

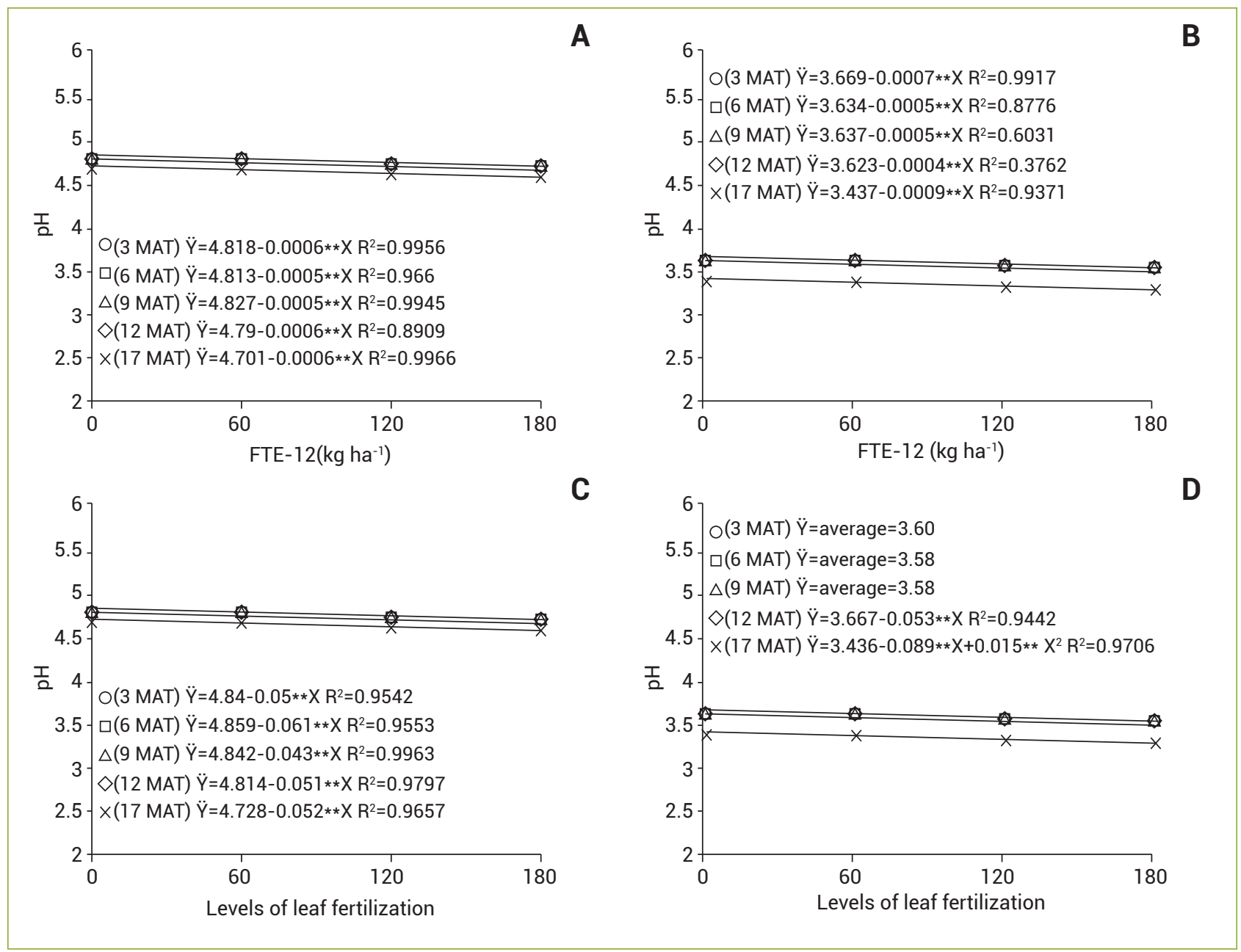

Figure 4. $\mathrm{pH}$ in leaves of pineapple cv. Vitória as a function of FTE-12 (A and B) doses and levels of foliar fertilization (C and D) at five sampling times $(3,6,9,12$ and 17 months after transplantation), analyzed at late afternoon (A and $\mathbf{C})$ and at the end of the night (B and D). *p<0.05; **p<0.01. 
Changes in $\mathrm{pH}$ and TA between day and night (Figures 3 and 4) reflect variations in acidity due to foliar CAM metabolism, with malate being the primary organic acid associated with increased acidity in pineapple plants (Medina et al. 1993, Chen et al. 2002). Nievola et al. (2005) conducted a study with Smooth Cayenne pineapple seedlings under two temperature regimes, $28^{\circ} \mathrm{C}$ for 24 hours and $28 / 15^{\circ} \mathrm{C}$ day/night, and found an increase in TA only when there was a reduction in night temperature. These authors concluded that pineapple plants acted as C3 ones when night temperatures remained high.

Differences in air temperature of about $5^{\circ} \mathrm{C}$ between day and night were recorded throughout the crop cycle (Table 2), which may explain the increase in TA associated with CAM metabolism. However, it is possible the occurrence of C3 metabolism, especially at the late afternoon, when the supply of $\mathrm{CO}_{2}$ generated by decarboxylation of organic acids, does not follow the demand of carbon dioxide for Calvin's cycle (Borland et al. 2011). According to Drennan and Nobel (2000) and Cushman (2001), when some CAM plants are under adequate soil moisture, the stomata can be opened during the day and closed at night; therefore, it presents metabolism similar to that of C3 plants. However, work conducted with three genotypes of pineapple plants demonstrated that they remained with the stomata closed most of the day, even with good water supply, and stomatal conductance equals to zero between 9 and 3 pm (Barreiro Neto et al. 2009). According to this study, the stomata began to open around $5 \mathrm{pm}$, stabilizing between 8 and 11:45 pm, with values of stomatal conductance from 2.8 to $2.7 \mathrm{~mm} \mathrm{~s}^{-1}$ in Perola cultivar, 4.2 to $4.8 \mathrm{~mm} \mathrm{~s}^{-1}$ and 3.5 to $3.9 \mathrm{~mm} \mathrm{~s}^{-1}$ in the hybrid Purple of Smooth Cayenne.

The intensity of the CAM metabolism may vary with environmental conditions and the developmental stage of the plant, including low night temperatures and favoring $\mathrm{CO}_{2}$ absorption and organic acids production during the night (Nievola et al. 2005, Borland et al. 2011). In the present study, there were no major changes in metabolism during the crop cycle, based on small variations in TA and $\mathrm{pH}$ between different samples (Figures 3 to 5). This constancy in acidification during the night could be related, at least in part, to small variations in the nighttime temperatures during the 17 months of observation (Table 2). It is noteworthy that only the $\mathrm{TA}$ and $\mathrm{pH}$ were evaluated and other biochemical variables, such as the activity of PEPCase, could help for better understanding the behavior of CAM metabolism over time (Nievola et al. 2005).

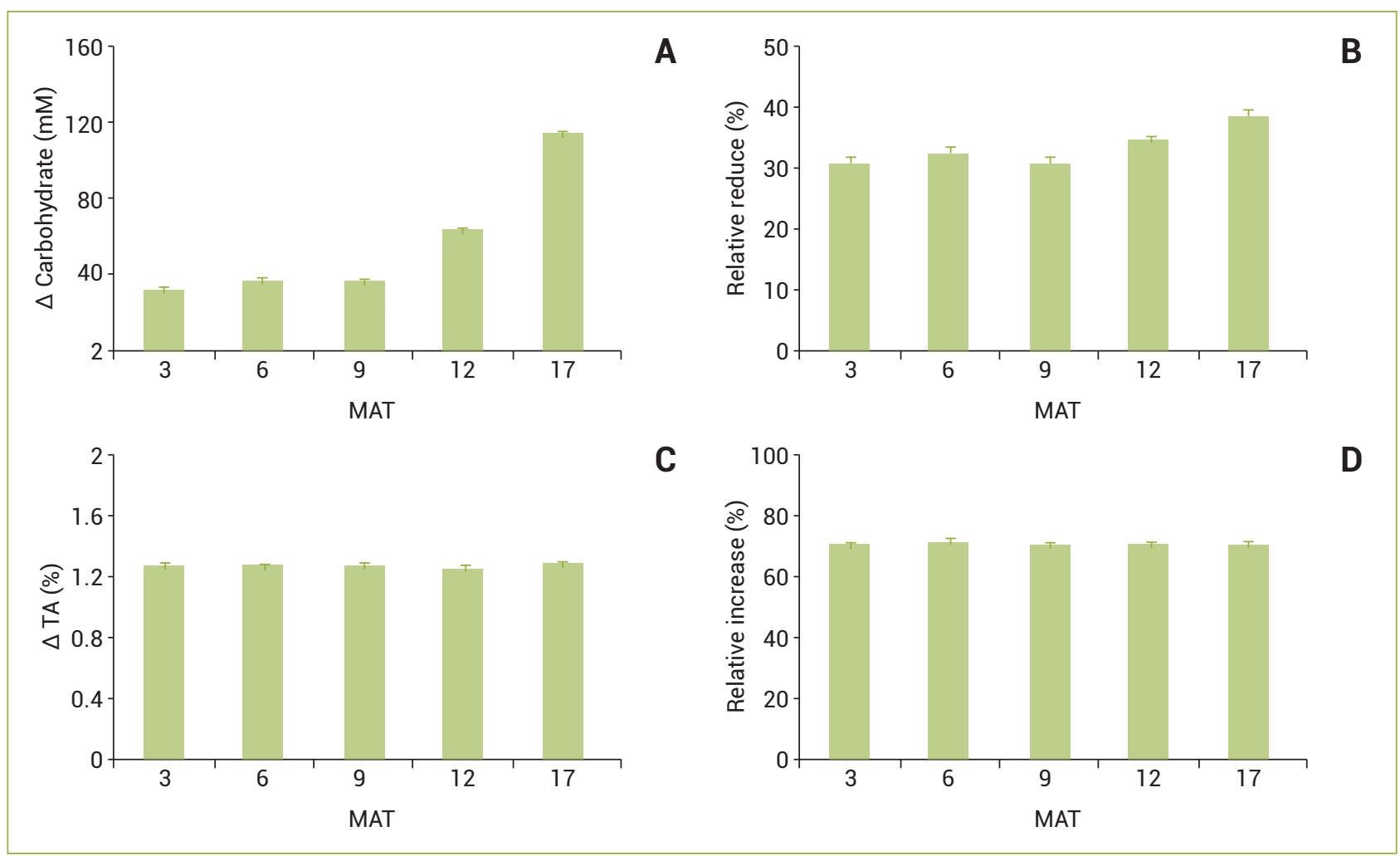

Figure 5. Diurnal and nocturnal changes in concentrations of soluble carbohydrates (A) and titratable acidity (C) with their respective percentage of decrease or increase (B and D), in leaves of pineapple cv. Vitória at five sampling times (3, 6, 9, 12 and 17 months after transplantation). 
Soil and leaf application of micronutrients provided increases in concentrations of carbohydrates and $\mathrm{N}$-aminosoluble compounds and reduction in leaf $\mathrm{pH}$ of pineapple plants, in both diurnal and nocturnal evaluations. The effects provided by treatments with micronutrients in the plant metabolism studied were more significant at the last sampling (17 MAT), when plants required a greater amount of organic compounds for the final process of inflorescence formation. Reductions in leaf concentrations of carbohydrates and increases in the acidity of leaves collected at the end of the night confirm the CAM metabolism

\section{REFERENCES}

Agbangba EC, Olodo GP, Dagbenonbakin GD, Kindomihou V, Akpo LE, Sokpon N (2011) Preliminary DRIS model parameterization to access pineapple variety 'Perola' nutrient status in Benin (West Africa). African Journal of Agricultural Research 6:5841-5847.

Barreiro Neto M, Fernandes PD, Gheyi HR, Santos ES, Fontinelli ISC (2009) Condutância estomática em genótipos de abacaxizeiro sob estresse salino. In: Anais do XII Congresso Brasileiro de Fisiologia Vegetal, Fortaleza, Ceará, Brazil. p. 212.

Bartholomew DP, Paull RE, Rohrbach KG (2003) The pineapple: botany, production and uses. CAB International, Wallingford.

Borland AM, Taybi T (2004) Synchronization of metabolic processes in plants with Crassulacean acid metabolism. Journal of Experimental Botany 55:1255-1265.

Borland AM, Zambrano VAB, Ceusters J, Shorrock K (2011) The photosynthetic plasticity of crassulacean acid metabolism: an evolutionary innovation for sustainable productivity in a changing world. New Phytologist 191:619-633.

Carnal NW, Black CC (1989) Soluble sugars as the carbohydrate reserve for CAM in pineapple leaves: implications for the role of pyrophosphate:6-phosphofructokinase in glycolysis. Plant Physiology 90:91-100.

Carvalho VD, Paula MB, Abreu CMP, Chagas SJR (1991) Efeito da época de colheita da planta na composição química das folhas de abacaxizeiro. Pesquisa Agropecuária Brasileira 26:1655-1661.

Ceusters J, Borland AM, Londers E, Verdoodt V, Godts C, Proft MP (2009) Differential usage of storage carbohydrates in the CAM bromeliad Aechmea 'Maya' during acclimation to drought and recovery from dehydration. Physiologia Plantarum 135:174-184.

Chen LS, Lin Q, Nose A (2002) A comparative study on diurnal changes in metabolite levels in the leaves of three crassulacean acid metabolism (CAM) species, Ananas comosus, Kalanchoe daigremontiana and $K$. pinnata. Journal of Experimental Botany 53:341-350.

Cushman JC (2001) Crassulacean acid metabolism. A plastic photosynthetic adaptation to arid environments. Plant Physiology 127:1349-1448. of pineapple plants. In relative terms, leaf carbohydrates and acidity were not affected either by application of micronutrients nor plant age. It could be concluded that the strategy of soil and leaf micronutrients application may help to alter positively the metabolism of pineapple plants, especially during flowering and fruit development.

\section{ACKNOWLEDGEMENTS}

We thank Banco do Nordeste do Brasil (BNB) and Conselho Nacional de Desenvolvimento Científico e Tecnológico (CNPq) for their financial support and scholarships.

Cushman JC, Agarie S, Albion S, Elliot SM, Taybi T, Borland AM (2008) Isolation and characterization of mutants of ice plant, Mesembryanthemum crystallinum, defective in Crassulacean acid metabolism. Plant Physiology 147:228-238.

Drennan PM, Nobel PS (2000) Responses of CAM species to increasing atmospheric $\mathrm{CO}_{2}$ concentrations. Plant, Cell and Environment 23:767-781.

Dubois M, Gilles KA, Hamilton JK, Rebers PA, Smith F (1956) Colorimetric method for determination of sugars and related substances. Analytical Chemistry 28:350-356.

Feitosa HO, Amorim AV, Lacerda CF, Silva FB (2011) Growth and micronutrients extraction by 'Vitoria' pineapple. Revista Brasileira de Fruticultura 33:706-712.

Huppe HC, Turpin DH (1994) Integration of carbon and nitrogen metabolism in plant and algal cells. Annual Review of Plant Physiology and Plant Molecular Biology 45:577-607.

Instituto Adolfo Lutz - IAL (1985) Normas analíticas, métodos químicos e físicos para análise de alimentos. 3. ed. São Paulo, IAL.

José JS, Montes R, Nikonova N (2007) Seasonal patterns of carbon dioxide, water vapour and energy fluxes in pineapple. Agricultural and Forest Meteorology 147:16-34.

Keller P, Luttge U (2005) Photosynthetic light-use by three bromeliads originating from shaded sites (Ananas ananassoides, Ananas comosus cv. Panare) and exposed sites (Pitcairnia pruinosa) in the medium Orinoco basin, Venezuela. Biologia Plantarum 49:73-79.

Leegood RC (2002) C4 photosynthesis: principles of $\mathrm{CO}_{2}$ concentration and prospects for its introduction into $\mathrm{C} 3$ plants. Journal of Experimental Botany 53:581-590.

Maeda AS, Buzetti S, Boliani AC, Benett CGS, Teixeira Filho MCM, Andreotti M (2011) Foliar fertilization on pineapple quality and yield. Pesquisa Agropecuária Tropical 41:248-253.

Mansour MMF (2000) Nitrogen containing compounds and adaptation of plants to salinity stress. Biologia Plantarum 43:491-500.

Martín M, Rius SB, Podestá FE (2011) Two phosphoenolpyruvate carboxykinases coexist in the Crassulacean Acid Metabolism plant 
Ananas comosus. Isolation and characterization of the smaller 65 kDa form. Plant Physiology and Biochemistry 49:646-653.

Medina E, Popp M, Olivares E, Janett HP, Lüttge U (1993) Daily fluctuations of titratable acidity, content of organic acids (malate and citrate) and soluble sugars of varieties and wild relatives of Ananas comosus L. growing under natural tropical conditions. Plant, Cell and Environment 16:55-63.

Moroney JV, Ynalvez RA (2007) Proposed carbon dioxide concentrating mechanism in Chlamydomonas reinhardtii. Eukaryotic Cell 6:1251-1259.

Murashige T, Skoog F (1962) A revised medium for rapid growth and bioassays with tobacco tissue culture. Physiologia Plantarum 15:473-497.

Nievola CC, Kraus JE, Freschi L, Souza BM, Mercier H (2005) Temperature determines the occurrence of CAM or C3 photosynthesis in pineapple plantlets grown in vitro. In Vitro Cellular and Developmental Biology-Plant 41:832-837.

Reinhardt DH, Cunha GAP (2010) Cultivo do abacaxizeiro. Jaboticabal, Funep. 45 p.
Siebeneichler SC, Monnerat PH, Carvalho AJC, Silva JA (2008) Boro in pineapple plants 'Pérola' in the north fluminense contents, distribution and characteristics of the fruit. Revista Brasileira de Fruticultura 30:787-793.

Soares AG, Trugo LC, Botrel N, Sousa LFS (2005) Reduction of internal browning of pineapple fruit (Ananas comusus L.) by preharvest soil application of potassium. Postharvest Biology and Technology 35:201-207.

Su NR (1975) Micronutrient problems in pineapples. Taipei, ASPAC/Food and Fertilizer Technology Center. 13p.

Ventura JA, Costa H, Cabral JRS, Matos AP (2009) Vitória: new Pineapple cultivar resistent to fusariosis. Acta Horticulturae 822:51-56.

Vieira DAP, Portes TA, Stacciarini-Seraphin E, Teixeira JB (2010) Fluorescence and levels of chlorophyll in pineapple plants cv. perola submitted to different concentration of ammonium sulphate. Revista Brasileira de Fruticultura 32:360-368.

Yemm EW, Cocking EC (1955) The determination of amino-acids with ninhydrin. Analyst 80:209-213 